\title{
Innovation Education and Diffusion in the United States: Using Literature Derived Knowledge Maps to Develop Research Methodology Strategy
}

\author{
Justin D. Fruehauf and Frederick G. Kohun \\ Robert Morris University, Pittsburgh, PA, USA
}

\author{
Jdfst18@mail.rmu.edu kohun@rmu.edu
}

\begin{abstract}
The notion of innovation has new meaning in the $21^{\text {st }}$ century. With his introduction of the ideas of disruptive innovations in the 1990s, Clayton Christensen became a leader in the field of innovation education. Christensen expanded his theory of disruptive innovation to encompass not only industry, but also healthcare and education. It is in this field of education that much work remains. Christensen proposes that innovative thinking can be learned. Indeed and entire field of innovation education and innovation curriculum now exist in a few US universities. It is the intent of this study to examine to use of knowledge maps of the literature of innovation education, as explained by the disruptive innovation model, to establish a research methodology of how innovation is taught in US education systems, specifically comparing vocational programs (machining), and graduate programs in business and engineering.
\end{abstract}

Keywords: Clayton Christensen, disruptive innovation, innovation education, vocational, curriculum

\section{Introduction}

The notion of innovation has new meaning in the $21^{\text {st }}$ century. With his introduction of the ideas of disruptive innovations in the 1990s, Clayton Christensen became a leader in the field of innovation education. Christensen expanded his theory of disruptive innovation to encompass not only industry, but also healthcare and education. It is in this field of education that much work remains. Christensen proposes that innovative thinking can be learned. Indeed and entire field of innovation education and innovation curriculum now exist in a few US universities. It is the intent of this study to examine to use of knowledge maps of the literature of innovation education, as explained by the disruptive innovation model, to establish a research methodology of how innovation is taught in US education sys-

Material published as part of this publication, either on-line or in print, is copyrighted by the Informing Science Institute. Permission to make digital or paper copy of part or all of these works for personal or classroom use is granted without fee provided that the copies are not made or distributed for profit or commercial advantage AND that copies 1) bear this notice in full and 2) give the full citation on the first page. It is permissible to abstract these works so long as credit is given. To copy in all other cases or to republish or to post on a server or to redistribute to lists requires specific permission and payment of a fee. Contact Publisher@InformingScience.org to request redistribution permission. tems, specifically comparing vocational programs (machining), and graduate programs in business and engineering.

\section{Background and Literature}

Due in large part to the ideas proposed by Clayton Christensen, the term innovation is now a buzz word for both in- 
dustry and academics. Business executives cite the need for continued innovation as a pillar of future economic success in the United States (US). In conjunction with this trend, colleges and universities promote revamped curriculum highlighting innovative theory as a critical component. Innovation in manufacturing is considered crucial to driving the economy (Bozic \& Dunlap, 2013). In order to achieve this goal in US manufacturing, it is critical to address the innovation of fields such as business, engineering, and machining.

Many graduate business programs offer courses in innovation education, categorized either as innovation education or entrepreneurship. As of 2012, the National Science Foundation reported a dearth of qualified engineering and machining candidates to fill the vacant positions in the United States. ("Science and engineering indicators," 2012). While colleges and universities attempt to fill the need for engineers in the United States, vocational schools offer the traditional path of educating qualified machinists. These fields are heavily intertwined for the creation and development of manufacturing processes and products. Both fields involve heavy course work with technology and information systems. Yet in both cases inclusion of innovation education is still lacking. Changes are occurring in engineering programs, but little work is done to understand the changes occurring for machining programs (Bozic \& Dunlap, 2013).

In 2009 the Obama Administration issued an initiative to generate and sustain innovation in the United States economy (National Economic Council 2009). In addition to proposing key elements for the industrial sector, the strategy highlights support for initiatives at the kindergarten through 12 th grade level as well as colleges and universities. The recognition of a need for an education strategy to increase innovation in the United States (US) demonstrates the importance placed on innovation for continued economic success in the $21^{\text {st }}$ century.

The discussion of teaching innovation implies that being innovative is a learned set of traits. A 2008 research study by Clayton Christensen and colleagues targeted the identification of innovative US executives and evaluated the traits or characteristics making them innovative (Dyer, Gregersen, \& Christensen, 2008). Its conclusion; that innovative executives possessed four behavioral patterns and two cognitive patterns. According to the study not only did all of the identified innovators possess the four traits and two skills, but variation in which traits were stronger in each individual was also recorded (Dyer, Gregersen, \& Christensen, 2008).

The aforementioned study is further expounded in "The Innovator's DNA", a work by the same authors (Dyer, et al.) highlighting the study's findings in the context of the original works by Clayton Christensen. Christensen first proposed his notion of innovation in the context of disruptive technologies in 1997. This idea developed into the idea of disruptive innovation: the introduction of an idea or technology into a niche market that over time fundamentally changes the paradigm for that market, almost violently displacing the previous hierarchy (Dyer, Gregersen, \& Christensen, 2011). "The Innovator's DNA" uses the ideas of disruptive innovation to isolate the disruptive innovators and identify the characteristic personality traits of the innovators. Additionally, they make the significant claim that innovative thinking can be learned (Dyer, Gregersen, \& Christensen, 2011).

Building on this notion that disruptively innovative thinking can be taught, Dyer, Christensen, and Gregersen propose strategies for developing the above mentioned traits. A quick overview of the traits and developmental strategies for them is highlighted in the table below (see Table 1): 
Table 1: Traits and Development Strategy

\begin{tabular}{|c|c|}
\hline Trait & Developmental Strategy \\
\hline $\begin{array}{l}\text { Questioning, or their propensity to frequently } \\
\text { ask questions, particularly those that challenge } \\
\text { the status quo and ask what if about the future } \\
\text { (Dyer et al., 2008) }\end{array}$ & 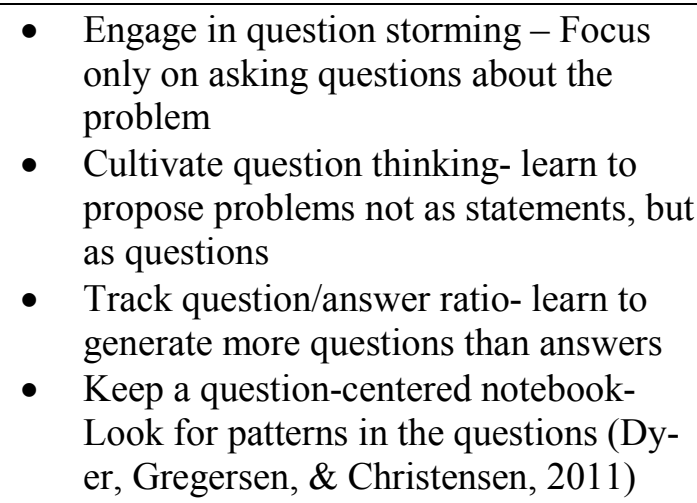 \\
\hline $\begin{array}{l}\text { Observing, or the extent to which they spend } \\
\text { time intensely observing the world around } \\
\text { them, paying attention to everyday experiences } \\
\text { to find new ideas (Dyer et al., 2008) }\end{array}$ & $\begin{array}{l}\text { - } \text { Observe real people in real-life situa- } \\
\text { tions- try to grasp what makes life easi- } \\
\text { er or more difficult } \\
\text { - } \text { Observe companies - Pick a company } \\
\text { and treat it like a case study. Learn eve- } \\
\text { rything a company does and how it } \\
\text { does it } \\
\text { - Observe anything that captures your at- } \\
\text { tention - Set aside } 10 \text { minutes a day to } \\
\text { observe something intensely and take } \\
\text { notes on it } \\
\text { Observe with all senses - Consciously } \\
\text { engage more than one sense when ob- } \\
\text { serving an environment (Dyer, } \\
\text { Gregersen, \& Christensen, 2011) }\end{array}$ \\
\hline
\end{tabular}




\begin{tabular}{|c|c|}
\hline $\begin{array}{l}\text { Experimenting, or the frequency with which } \\
\text { they experiment in and explore the world with } \\
\text { a hypothesis-testing mindset: visiting new } \\
\text { places, trying new things, seeking new infor- } \\
\text { mation, and experimenting to learn new things, } \\
\text { as experimenters constantly explore the world } \\
\text { intellectually and experientially, holding con- } \\
\text { victions at bay, testing hypotheses along the } \\
\text { way (Dyer et al., 2008) }\end{array}$ & 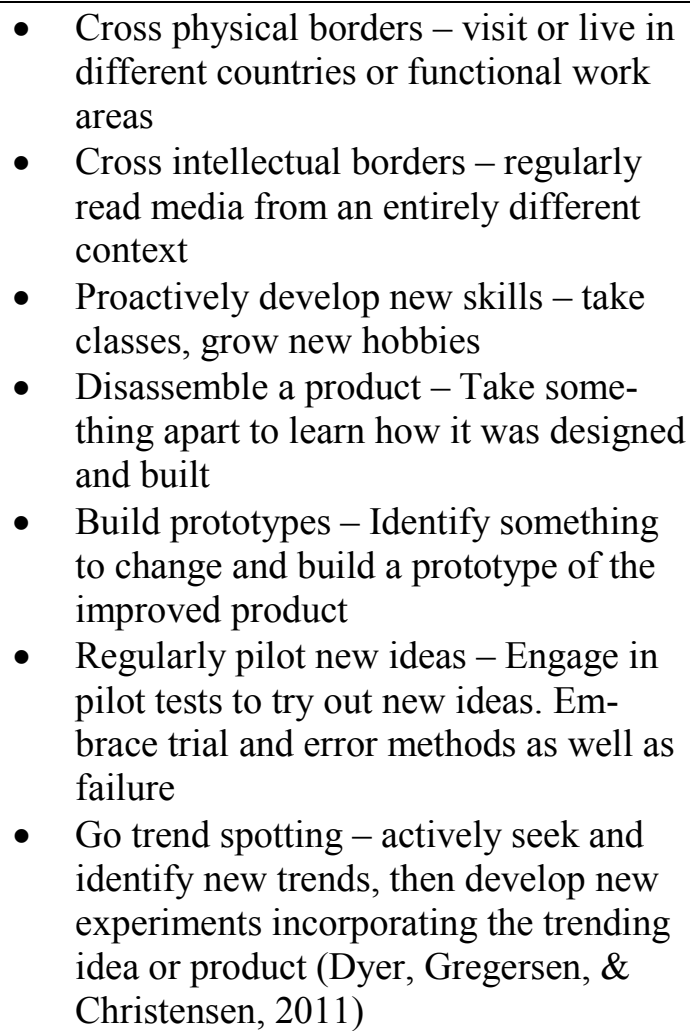 \\
\hline $\begin{array}{l}\text { Idea networking, or the extent to which they } \\
\text { actively find and test ideas with a network of } \\
\text { individuals who are diverse in both back- } \\
\text { ground and perspective (Dyer et al., 2008) }\end{array}$ & $\begin{array}{l}\text { - Expand the diversity of network - iden- } \\
\text { tify and visit with people most different } \\
\text { from self } \\
\text { - Start a "mealtime networking" plan - } \\
\text { have a meal with someone from a dif- } \\
\text { ferent background at least once a week } \\
\text { - Attend conferences - Plan to attend two } \\
\text { conferences annually, one in area of } \\
\text { expertise and one on an unrelated topic } \\
\text { - Start a creative community - start a } \\
\text { group of individuals interested in dis- } \\
\text { cussing new ideas } \\
\text { Engage outsiders - Invite an outsider } \\
\text { from a different area of expertise to of- } \\
\text { fer their perspective on an innovation } \\
\text { challenge } \\
\text { Cross-train - find experts in different } \\
\text { areas and sit in on their training ses- } \\
\text { sions (Dyer, Gregersen, \& Christensen, } \\
\text { 2011) }\end{array}$ \\
\hline
\end{tabular}


Associating (Pattern Recognition) - cognitive patterns: pattern recognition and a desire to change the status quo
- Force New Associations-Combine things not naturally combined

- Assume a different persona - learn to approach a problem from two perspectives

- Generate Metaphors - Each analogy may reveal a new perspective

- Develop a curiosity box - when examining a problem randomly pick up different items from the box to stimulate a different outlook

- Use the SCAMPER strategy - substitute, combine, adapt, modify, put to other use, eliminate, rearrange (Dyer, Gregersen, \& Christensen, 2011)

Given the authors' identification of innovator traits, and their hypothesis that these characteristics can be learned, the question then becomes, is innovation education, as described by disruptive innovation theory, taught in the United States and elsewhere? If so how is it taught?

\section{Knowledge Mapping}

In order to methodically address the problem of innovation and whether or not it can be taught, the study needed purposeful contextualization. As previously stated, the purpose of this study is to ascertain whether innovation education, as defined by Clayton Christensen's theory of disruptive innovation is actually taught in the United States. In particular this study is to examine graduate level business programs, graduate level engineering programs, and vocational machining programs. The rationale for the selection of these particular programs is that they form the core of manufacturing personnel in the United States and are therefore at the forefront of innovation as discussed in the White House Doctrine.

Given the complexity and multidimensionality of this problem, the following research questions form the context of a conceptual map to both understand and study the basis of the problem:

1. What constitutes innovation education?

2. If so where is it taught? Universities, vocational schools?

3. What is being taught?

4. Who determines the curriculum?

5. What is the role of culture in innovation education?

6. What tools or methods are used to teach innovation?

7. How is the success of the program measured?

8. What is the role of accreditation?

The establishment of a conceptual infrastructure for analysis of the many dimensions of the problem of whether or not innovation can be taught led to the development of a knowledge map focusing on the literature reflective of the identifiable components of Christensen's notion. The following knowledge map (Figure 1) is the result of a number of iterations of discovery that was derived from relevant segments of literature related to innovation, its dissemination and education. The figure segments the problem into eight distinct yet interrelated conceptual schema that together form a frame of analysis to address whether or not innovation education exists in the 
United States. The above listed questions form the core focus of each of the eight dimensions of the knowledge map conceptualizing the focus of study.

\section{Figure 1 Knowledge Map Derived from the Literature}

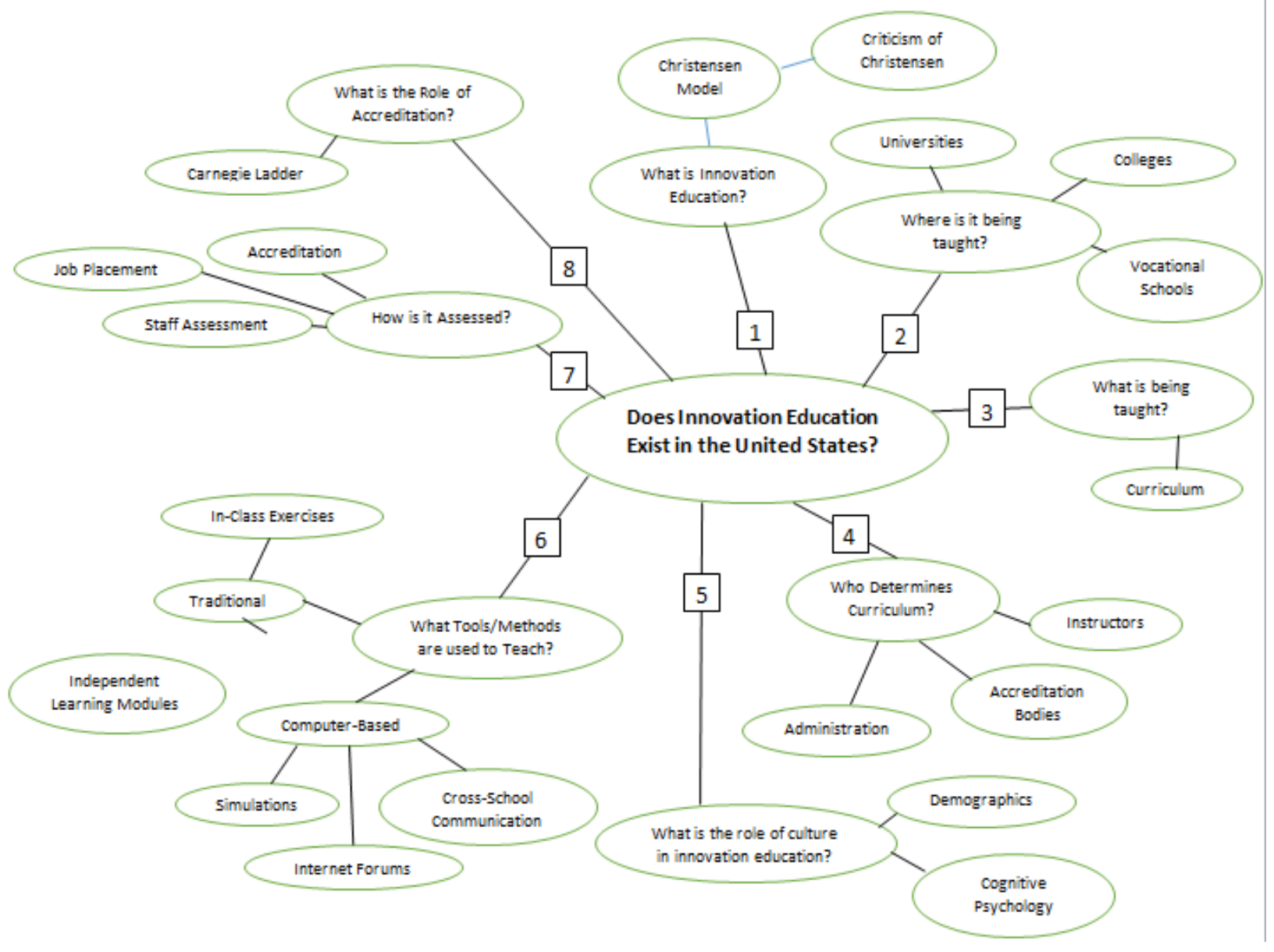

\section{Methodological Considerations}

The knowledge map then becomes the basis for a methodological plan to validate the basic research questions. The literature that is the foundation for the knowledge map drives both the data need and the research methodology used to attain that data. The questions culled from the literature review led to the development of the methodology used to conduct the research project. This methodology is depicted in Figure 2. 


\section{Figure 2 Methodology of Innovation Education-Visually Derived from a Literature Based Knowledge Map}

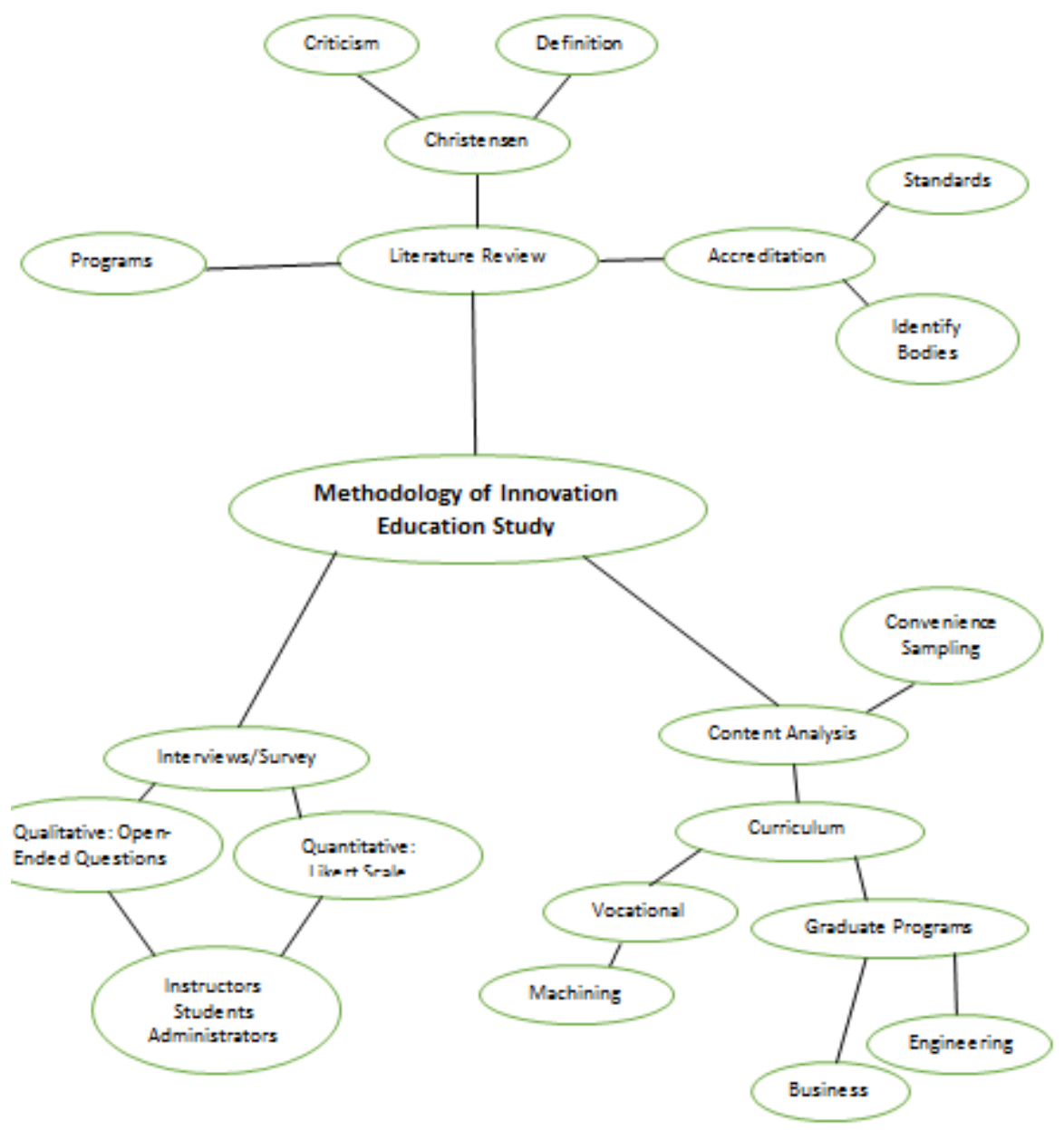

Essentially the literature drives a series of questions that drives a research design that utilizes a mixed methods approach. In specific, visualization of the complexities and issues uncovered with the knowledge map lead to a methodology based on interview/surveys directed toward instructors, students, and administrators as well as a content analysis directed toward existing curricula derived from a diverse program convenience sampling context.

\section{Conclusion}

The paper presented a framework for establishing a research methodology appropriate to the complexities and diversity of issues related to whether innovation can be taught as defined by Clayton Christensen. Through a discussion of the traits and development strategy associated with innovators and innovation eight research questions derived from the literature were established. These eight questions became the basis for a knowledge map that attempts to provide a visual conceptual foundation to help understand the factors that lead to answering whether or not innovation education, as defined by Christensen, exists in the United States. Finally, it is this literature base knowledge map and its questions that become the methodological foundation for a focused research study. This paper describes knowledge mapping and visualization as a technique that is both a useful and viable tool for establishing research methodology. 


\section{References}

Bozic, C., \& Dunlap, D. (2013). The role of innovation education in student learning, economic development, and university engagement. Journal of Technology Studies, 39(2), 102-111.

Dyer, J. H., Gregersen, H. B., \& Christensen, C. M. (2008). Entrepreneur behaviors, opportunity recognition, and the origins of innovative ventures. Strategic Entrepreneurship Journal, 2, 317-338.

Dyer, J. H., Gregersen, H. B., \& Christensen, C. M. (2011). The innovator's DNA. Boston, MA. Harvard Business Review Press.

National Economic Council. (2009). A strategy for American innovation: Driving towards sustainable growth and quality jobs. Washington, DC. Accessed 6-29-2012 from http://www.whitehouse.gov/innovation/strategy

National Science Foundation. (2012). Science and engineering indicators 2012. (NSB12-01). January 2012. Retrieved from http://www.nsf.gov/statistics/seind12/c3/c3h.htm

\section{Biographies}

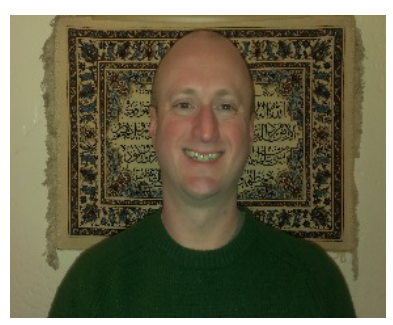

Justin Fruehauf, is a doctorate of science candidate in the School of Communication and Information Systems at Robert Morris University in Pittsburgh, PA. He holds a bachelor degree in history from Georgetown University, a graduate degree in information science management and a graduate degree in information security and assurance, both from Robert Morris University. He has over 15 years of experience working with information systems in various industries. He is currently the Vice President of Fruehauf Manufacturing and Tate-

Jones, Inc. in Pittsburgh, PA.

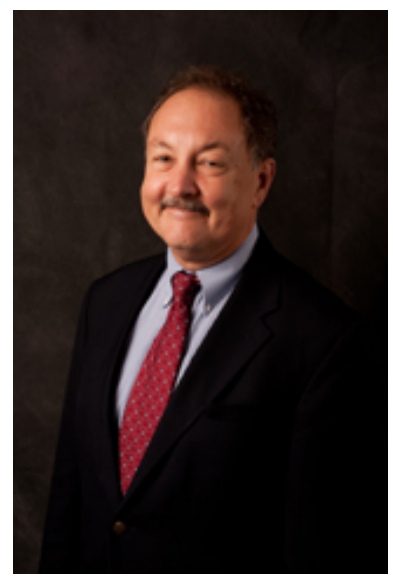

Frederick G. Kohun, Ph.D., University Professor in the School of Communications and Information Systems at Robert Morris University in Pittsburgh, has more than 38 years of experience as a professor and administrator in the information systems field. He holds a bachelor degree in economics from Georgetown University, graduate degrees in economics and information science, from the University of Pittsburgh, and a Ph.D. in applied history in technology from Carnegie Mellon University. He had a leadership role in the design and implementation of eight technology based academic programs at the undergraduate and graduate level including a doctoral program. He was involved in the first round of ABET-CAC information systems accreditation. He was the 2007 IACIS Computer Educator of the Year. 